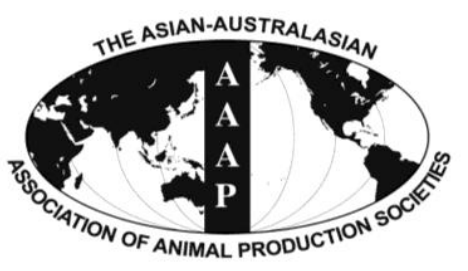

Asian Australas. J. Anim. Sci.

Vol. 26, No. 11 : 1583-1591 November 2013

http://dx.doi.org/10.5713/ajas.2013.13182

www.ajas.info

pISSN 1011-2367 elSSN 1976-5517

\title{
Changes of Microbial Population in the Rumen of Dairy Steers as Influenced by Plant Containing Tannins and Saponins and Roughage to Concentrate Ratio
}

\author{
N. Anantasook, M. Wanapat*, A. Cherdthong, and P. Gunun \\ Tropical Feed Resources Research and Development Center (TROFREC), Department of Animal Science, \\ Faculty of Agriculture, Khon Kaen University, Khon Kaen, 40002, Thailand
}

\begin{abstract}
The objective of this study was to investigate microbial population in the rumen of dairy steers as influenced by supplementing with dietary condensed tannins and saponins and different roughage to concentrate ratios. Four, rumen fistulated dairy steers (Bos indicus) were used in a $2 \times 2$ factorial arrangement in a $4 \times 4$ Latin square design. The main factors were two roughage to concentrate ratios (R:C, 60:40 and 40:60) and two supplementations of rain tree pod meal (RPM) (0 and $60 \mathrm{~g} / \mathrm{kg}$ of total DM intake). Chopped $30 \mathrm{~g} / \mathrm{kg}$ urea treated rice straw was used as a roughage source. All animals received feed according to respective R:C ratios at $25 \mathrm{~g} / \mathrm{kg}$ body weight. The RPM contained crude tannins and saponins at 84 and $143 \mathrm{~g} / \mathrm{kg}$ of DM, respectively. It was found that ruminal $\mathrm{pH}$ decreased while ruminal temperature increased by a higher concentrate ratio ( $\mathrm{R}: \mathrm{C} 40: 60)(\mathrm{p}<0.05)$. In contrast, total bacterial, Ruminococus albus and viable proteolytic bacteria were not affected by dietary supplementation. Numbers of fungi, cellulolytic bacteria, Fibrobactor succinogenes and Ruminococus flavefaciens were higher while amylolytic bacteria was lower when steers were fed at 400 $\mathrm{g} / \mathrm{kg}$ of concentrate. The population of Fibrobactor succinogenes, was found to be higher with RPM supplementation. In addition, the use of real-time PCR technique indicated that the population of protozoa and methanogens were decreased $(\mathrm{p}<0.05)$ with supplementation of RPM and with an increasing concentrate ratio. Supplementation of RPM and feeding different concentrate ratios resulted in changing the rumen microbes especially, when the animals were fed at $600 \mathrm{~g} / \mathrm{kg}$ of concentrate and supplemented with RPM which significantly reduced the protozoa and methanogens population. (Key Words: Tannins, Saponins, Microbial Population, Roughage to Concentrate Ratio, Rumen)
\end{abstract}

\section{INTRODUCTION}

Manipulation of the ruminal microbial ecosystem to enhance fibrous feed digestibility, reduce methane emission and nitrogen excretion by ruminants to improve their feed utilization is one of the most important goals for animal nutritionists (Patra et al., 2006).

The type of feed offered to a ruminant can have a major effect on rumen fermentation. The types of diet are potential modifiers of ruminal fermentation and may offer a strategy to reduce protozoal and methanogen populations, thus improving the efficiency of feed utilization in the ruminants (Anantasook and Wanapat, 2012). When the ratio of concentrate in the diet was increased methane production decreased by shift of hydrogen from the methane pathway

\footnotetext{
* Corresponding Author: Metha Wanapat. Tel: +66-43-202368, Fax: +66-43-202368, E-mail: metha@kku.ac.th Submitted Apr. 2, 2013; Accepted Jun. 14, 2013; Revised Jul. 15, 2013
}

to be used to produce propionate (Poungchompu et al., 2009). Plants containing secondary metabolites and condensed tannins and saponins have shown potential to manipulate rumen fermentation by enhancing the efficiency of utilization of feed energy while inhibiting rumen methane production (Kreuzer et al., 2009; Wang et al., 2009; Mao et al., 2010). Moreover, plant secondary compounds with action against specific microbial groups can be used to inhibit of some undesirable microbes in the rumen. The methanogens classified as Archaea have a distinctly different cell wall structure from true rumen bacteria (Woese et al., 1990). Thus, there exists a possibility that some of the plant secondary compounds might act as a selective inhibitor of methanogens and protozoa. Therefore, recent research has been focused on exploiting plant secondary compounds as natural feed additives to improve rumen fermentation such as enhancing protein metabolism, decreasing methane production (Wallace et al., 2002; Kamra et al., 2008; Chanthakhoun et al., 2011), affecting 
microbial activity (Patra et al., 2006), increasing reproductive efficiency (Ramirez-Restrepo et al., 2005), reducing nutritional stress such as bloat and improving animal health and productivity (Decandia et al., 2000; Patra, 2007). Thus, the aim of this study was to investigate microbial population in the rumen of dairy steers as influenced by supplementing with dietary condensed tannins and saponins and different roughage to concentrate ratios.

\section{MATERIALS AND METHODS}

\section{Animals, diets and experimental design}

Four-fistulated Holstein-Friesian crossbred (75\%) dairy steers with initial body weight (BW) of $270 \pm 15 \mathrm{~kg}$ were randomly assigned according to a $2 \times 2$ factorial arrangement in $4 \times 4$ Latin square design (LSD). The main factors were roughage to concentrate ratio (R:C, 60:40 or 40:60) and supplementation of rain tree (Samanea saman) pod meal or RPM at 0 and $60 \mathrm{~g} / \mathrm{kg}$ of total DM intake.

Rain tree is a local tree legume; pods of which can be dried and ground into a meal for animal feed (Chareprasert et al., 2006). It contains $23.5 \%$ of CP, $18.2 \%$ of total sugar and $8.4 \%$ of sucrose (Jetana et al., 2008). The RPM was prepared by the following, i) collect rain tree pods with black-brown coloration from ground; ii) chop rain tree pods with chopping machine; iii) sun-dry rain tree pods for twothree days; iv) grind rain tree pods with grinding machine.

The concentrate mixed diets were formulated to be at $140 \mathrm{~g} / \mathrm{kg}$ DM of CP. All animals received feed according to respective $\mathrm{R}: \mathrm{C}$ ratios at $25 \mathrm{~g} / \mathrm{kg}$ body weight and chopped $30 \mathrm{~g} / \mathrm{kg}$ urea treated rice straw (UTRS) was used as a roughage source. The rain tree pod meal (mixed with concentrate) was supplemented at 0 and $60 \mathrm{~g} / \mathrm{kg}$ of total DM intake. The ingredients and chemical composition of diets are shown in the Table 1.

All animals were kept in individual pens and received free choice of clean fresh water and mineral block. The experiment was conducted over four periods, each period lasted $21 \mathrm{~d}$. During the first $14 \mathrm{~d}$, all animals were fed their respective diets, whereas the last $7 \mathrm{~d}$, they were moved to metabolism crates for total collection of feces and urine.

\section{Data collection, analysis and sampling procedures}

At the end of each period, rumen fluid and digesta were collected at 0, 2, 4, and 6 h-post feeding. Approximately $200 \mathrm{~mL}$ of rumen fluid was collected at each time from the middle part of the rumen by using a $60 \mathrm{~mL}$ hand syringe. Ruminal temperature and $\mathrm{pH}$ were measured using a portable $\mathrm{pH}$ and temperature meter (Hanna Instruments $\mathrm{HI}$ 8424 microcomputer, Singapore). Rumen fluid samples were then filtered through four layers of cheesecloth. Samples were divided into 3 portions, the first portion was
Table 1. Ingredients and chemical composition of concentrate, urea treated rice straw and rain tree pod meal used in the experiment

\begin{tabular}{|c|c|c|c|}
\hline$\overline{\text { Item }}$ & Concentrate & $\mathrm{UTRS}^{1}$ & $\mathrm{RPM}^{2}$ \\
\hline \multicolumn{4}{|l|}{ Ingredient ( $\mathrm{g} / \mathrm{kg}$ of dry matter) } \\
\hline Cassava chip & 619 & & \\
\hline Rice bran & 109 & & \\
\hline Brewery grain & 109 & & \\
\hline Palm kernel meal & 93 & & \\
\hline Urea & 25 & & \\
\hline Molasses & 20 & & \\
\hline Mineral premix & 10 & & \\
\hline Salt & 10 & & \\
\hline Sulfur & 5 & & \\
\hline \multicolumn{4}{|l|}{ Chemical composition } \\
\hline \multirow[t]{2}{*}{ Dry matter $(\mathrm{g} / \mathrm{kg})$} & 910 & 514 & 926 \\
\hline & \multicolumn{2}{|c|}{$\mathrm{g} / \mathrm{kg}$ of dry matter } & \\
\hline Organic matter & 922 & 861 & 956 \\
\hline Crude protein & 142 & 55 & 164 \\
\hline Condensed tannins & - & - & 84 \\
\hline Crude saponins & - & - & 143 \\
\hline Neutral detergent fiber & 181 & 730 & 281 \\
\hline Acid detergent fiber & 151 & 543 & 230 \\
\hline Total digestible nutrients ${ }^{3}$ & 760 & 511 & - \\
\hline
\end{tabular}

fixed with $10 \%$ formalin solution (1:9 v/v, rumen fluid: $10 \%$ formalin) for measuring microbial population by total direct count of bacteria, protozoa and fungal zoospores with a hemocytometer (Boeco, Hamburg, Germany) using methods of (Galyean, 1989). The second portion was cultured using a roll-tube technique (Hungate, 1969) for identifying bacteria groups (cellulolytic, proteolytic, amylolytic and total viable bacteria counts). The third portion was stored at $-20^{\circ} \mathrm{C}$ for DNA extraction ( $\mathrm{Yu}$ and Morrison, 2004). Content of condensed tannins in RPM was analysed by using the modified vanillin- $\mathrm{HCl}$ method based on Burns (1971). Crude saponins were measured by using methanol extraction following the method of Kwon et al. (2003) and modified by Poungchompu et al. (2009).

\section{Rumen microbial population}

Community deoxyribonucleic acids (DNA) extraction: Community DNA was extracted from $2.0 \mathrm{~mL}$ aliquots of each sample by the $\mathrm{RBB}+\mathrm{C}$ method (Yu and Morrison, 2004). In brief, cell lysis is achieved by bead-beating in the presence of $4 \%$ (w/v) sodium dodecyl sulfate (SDS), 500 $\mathrm{mM} \mathrm{NaCl}$, and $50 \mathrm{mM}$ EDTA. The buffer should also protect the released DNA from degradation by DNases, which are very active in rumen and gastrointestinal samples. After bead-beating, most of the impurities and the SDS are 
removed by precipitation with ammonium acetate and then the nucleic acids are removed by precipitation with isopropanol. Genomic DNA can then purified via sequential digestion with RNase $\mathrm{A}$ and proteinase $\mathrm{K}$, and the DNA are purified using columns from QIAgen DNA Mini Stool Kit (QIAGEN, Valencia, CA, USA).

Primers and polymerase chain reaction $(P C R)$ : The primers used for the real-time PCR were as follows: primers for Fibrobactor succinogenes, Fs219f (5'GGT ATG GGA TGA GCT TGC-3') and Fs654r (5'-GCC TGC CCC TGA ACT ATC- 3'), were selected to allow amplification (446-bp product) of all $10 \mathrm{~F}$. succinogenes strains. For Ruminococcus albus primers, Ra1281f (5'-CCC TAA AAG CAG TCT TAG TTC G-3') and Ra1439r (5' CCT CCT TGC GGT TAG AAC A- 3') (175-bp product). Ruminococcus flavefaciens primers, Rf154f (5'-TCT GGA AAC GGA TGG TA-3') and Rf425r (5'- CCT TTA AGA CAG GAG TTT ACA A-3'), were also selected to allow species-species amplification (295 bp) of all seven $R$. flavefaciens strains deposited in GenBank. All these primer sets were previously published by Koike and Kobayashi (2001). For methanogens primers, forward primers (5'TTCGGTGGATCDCARAGRGC-3') and reverse primers (5'-GBARGTCGW- AWCCGTAGAATCC -3') were employed as described by Denman et al. (2005). Regular PCR conditions for $F$. succinogenes were as follows: $30 \mathrm{~s}$ at $94^{\circ} \mathrm{C}$ for denaturing, $30 \mathrm{~s}$ at $60^{\circ} \mathrm{C}$ for annealing and $30 \mathrm{~s}$ at $72^{\circ} \mathrm{C}$ for extension (48 cycles), except for the $9 \mathrm{~min}$ denaturation in the first cycle and the 10 min extension in the last cycle. Amplification of 16S rRNA gene for the other two species was carried out similarly except an annealing temperature of $55^{\circ} \mathrm{C}$ was used. The PCR conditions for methanogens were as follows; $30 \mathrm{~s}$ at $94^{\circ} \mathrm{C}$ for denaturing, $30 \mathrm{~s}$ at $58^{\circ} \mathrm{C}$ for annealing and $90 \mathrm{~s}$ at $72^{\circ} \mathrm{C}$ for extension (35 cycles) (Wright et al., 2004). Quantification of total bacteria population, primer and condition, was previously published by Kongmun et al. (2010).

Real-time PCR: The targeted bacteria were cellulolytic bacteria ( $F$. succinogenes, $R$. albus and R. flavefaciens), methanogenic bacteria and protozoa. To establish a quantitative assay, specific primers and PCR conditions as described previously were used to amplify target $16 \mathrm{~s}$ rDNA of each species. The purified DNA was quantified by spectrophotometry with multiple dilutions. The target DNA was quantified by using serial 10-fold dilutions from $10^{1}$ to $10^{8}$ DNA copies of the previously quantified DNA standards. Real-time PCR amplification and detection were performed in a Chromo 4 system (Bio-Rad, USA). In brief, Biostools QuantiMix Easy SYG Kit was used for PCR amplification samples were assayed in duplicate in a $20 \mu \mathrm{L}$ reaction mixture contained 4 to $6 \mathrm{mM} \mathrm{MgCl}_{2}, 10 \mu \mathrm{L}$ of Master mix (including; Taq DNA polymerase, reaction buffer, dNTP mixture, $\mathrm{MgCl}_{2}$ and SybrGreen), $2 \mu \mathrm{L}$ of DNA template, and $0.8 \mu \mathrm{L}$ of each primer $(10 \mu \mathrm{M} / \mu \mathrm{L})$.

External standards for real-time PCR were prepared from a simulated rumen matrix. For each standard, linear regressions derived from the threshold cycle $[\mathrm{C}(\mathrm{t})]$ of each DNA dilution versus the $\log$ quality (Figure 1) were calculated. Logarithms of the DNA concentration (copies $/ \mathrm{mL}$ ) were plotted against the calculated means (Figure 1), obtaining a straight line of equations $\mathrm{y}=$ $-0.3311 x+11.61, y=-0.2557 x+11.56, y=-0.4427 x+12.08$, $y=-0.3196 x+11.36, y=-0.3122 x+10.55$ and $y=-0.2698 x$ +12.02 (where $\mathrm{y}$ is the $\log$ of DNA concentration and $\mathrm{x}$ is the $\mathrm{Ct})$, with a linear correlation coefficient $\left(\mathrm{r}^{2}\right)$ of 0.992 , $0.993,0.994,0.995,0.997$, and 0.991 for total bacteria (Figure 1a), F. succinogenes (Figure 1b), R. flavefaciens (Figure 1c) and R. albus (Figure 1d), methanogens (Figure 1e) and protozoa (Figure 1f), respectively. These equations were used to quantify DNA from rumen digesta samples. The accuracy of each real-time PCR was validated by quantifying known numbers of target species templates (total bacteria, F. succinogenes, R. flavefaciens and R. albus, methanogens and protozoa).

\section{Statistical analysis}

All data were analyzed as a $2 \times 2$ factorial arrangement in a Latin square design (LSD) using the general linear procedure in PROC GLM of SAS (1996). The statistical model included terms for $\mathrm{R}: \mathrm{C}$ ratio, supplementation of $\mathrm{RPM}$, and interactions between $\mathrm{R}: \mathrm{C}$ ratio and supplementation of RPM. Differences between treatment means were determined by Duncan's New Multiple Range Test (Steel and Torrie, 1980).

\section{RESULTS AND DISCUSSION}

\section{Chemical composition of diets}

Experimental feeds and their chemical compositions are shown in Table 1. The mixture of concentrate, consisting of available local feed resources such as energy source (cassava chips and rice bran), protein sources (brewery grain and palm kernel meal) and non-protein nitrogen (urea), had a higher quality in terms of CP and low in fiber (142 and $181 \mathrm{~g} / \mathrm{kg}$ of DM, respectively). The RPM contained 164 , 84 and $143 \mathrm{~g} / \mathrm{kg}$ of DM of CP, crude tannins (CT) and crude saponins (CS), respectively. Anantasook et al. (2013) also found that CT and CS content of RPM were 84 and 143 $\mathrm{g} / \mathrm{kg}$ of DM, respectively. However, Jetana et al. (2010) reported that tannin values in the rain tree pod were $79 \mathrm{~g} / \mathrm{kg}$ of DM. The nutritive value of rice straw was improved in terms of CP by treatment with $30 \mathrm{~g} / \mathrm{kg}$ of DM of urea. The $\mathrm{CP}$ and NDF content of $30 \mathrm{~g} / \mathrm{kg}$ urea treated rice straw were 55 and $730 \mathrm{~g} / \mathrm{kg}$ of DM, respectively. This roughage source 

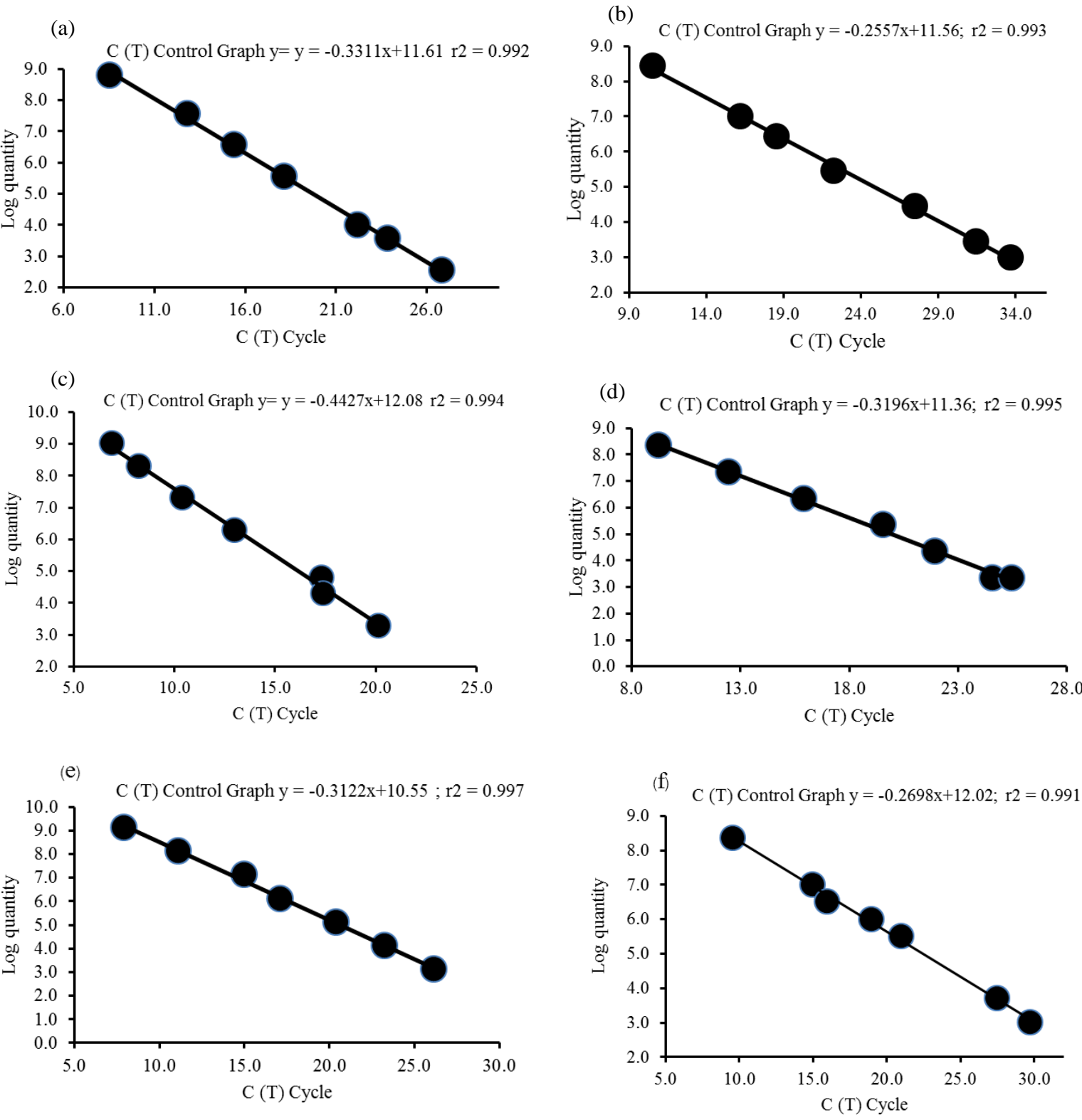

Figure 1. The standard curves obtained by plotting the logarithm of DNA concentration for total bacteria (a), F. succinogenes (b), $R$. flavefaciens (c), R. albus (d) methanogens (e) and protozoa (f) versus threshold cycle (Ct) for population quantification by using real time PCR.

was well consumed by animals during the experimental periods.

\section{Effect on ruminal pH, temperature and $\mathrm{NH}_{3}-\mathrm{N}$}

In the present study, the ruminal $\mathrm{pH}$, temperature and $\mathrm{NH}_{3}-\mathrm{N}$ were affected by $\mathrm{R}: \mathrm{C}$ ratio and $\mathrm{RPM}$ supplementation as presented in Table 2. The result showed that ruminal $\mathrm{pH}$ at $6 \mathrm{~h}$-post feeding was decreased with an increased level of concentrate in the diet. Similarly, Gaafar et al. (2009) and Cherdthong et al. (2010) found that diets containing $60 \%$ or more concentrate usually caused a marked reduction in ruminal $\mathrm{pH}$. However, the animals did not show clinical signs of acidosis under this study. Van
Soest (1994) suggested that a rumen $\mathrm{pH}$ below 6.2 inhibited the rate of digestion and depressed cellulolytic activity. Ruminal temperature was found higher in the treatment with $\mathrm{R}: \mathrm{C}$ at 40:60 due to the rapid fermentation rate of high concentrate in the diet. However, the values were stable at 38.8 to $39.3^{\circ} \mathrm{C}$ and similar to the result reported by Cherdthong et al. (2010). Moreover, $\mathrm{NH}_{3}-\mathrm{N}$ concentration in the high concentrate ratio fed group was higher than those fed with the lower ratio, $(24.1$ and $22.8 \mathrm{mg} / \mathrm{dL}$ for T3 and $\mathrm{T} 4$, respectively) and this result was similar to those of Gaafar et al. (2009) and Flachowsky et al. (2006). The differences may be due to a higher enzymatic breakdown of the dietary soluble fraction in high ratio of concentrate. 
Table 2. Effect of roughage to concentrate ratio and rain tree pod meal supplementation on ruminal $\mathrm{pH}$, temperature, ammonia nitrogen and blood urea nitrogen concentration

\begin{tabular}{|c|c|c|c|c|c|c|c|c|}
\hline \multirow{3}{*}{ Item } & \multicolumn{4}{|c|}{$\mathrm{R}: \mathrm{C}$ ratio ${ }^{1}$} & \multirow{3}{*}{ SEM } & \multirow{2}{*}{\multicolumn{3}{|c|}{ Significance $^{3}$}} \\
\hline & \multicolumn{2}{|c|}{$60: 40$} & \multicolumn{2}{|c|}{$40: 60$} & & & & \\
\hline & nRPM & $\mathrm{RPM}^{2}$ & nRPM & RPM & & $\mathrm{A}$ & $\mathrm{B}$ & $\mathrm{A} \times \mathrm{B}$ \\
\hline \multicolumn{9}{|l|}{$\overline{\text { Ruminal } \mathrm{pH}}$} \\
\hline $0 \mathrm{~h}$-post feeding & 6.4 & 6.4 & 6.3 & 6.3 & 0.03 & ns & $\mathrm{ns}$ & $\mathrm{ns}$ \\
\hline 2 & 6.3 & 6.2 & 6.3 & 6.3 & 0.03 & ns & ns & $\mathrm{ns}$ \\
\hline 4 & 6.3 & 5.8 & 6.1 & 5.9 & 0.10 & ns & ns & $\mathrm{ns}$ \\
\hline 6 & $6.1^{\mathrm{a}}$ & $6.1^{\mathrm{a}}$ & $5.9^{\mathrm{b}}$ & $5.8^{\mathrm{b}}$ & 0.04 & $*$ & $\mathrm{~ns}$ & $\mathrm{~ns}$ \\
\hline Mean & 6.3 & 6.2 & 6.3 & 6.2 & 0.04 & ns & $\mathrm{ns}$ & $\mathrm{ns}$ \\
\hline \multicolumn{9}{|l|}{ Temperature $\left({ }^{\circ} \mathrm{C}\right)$} \\
\hline $0 \mathrm{~h}$-post feeding & 38.1 & 39.0 & 39.3 & 39.3 & 0.27 & ns & ns & $\mathrm{ns}$ \\
\hline 2 & 38.8 & 39.3 & 39.3 & 39.1 & 0.14 & ns & ns & $\mathrm{ns}$ \\
\hline 4 & $39.1^{\mathrm{a}}$ & $39.2^{\mathrm{a}}$ & $39.8^{\mathrm{b}}$ & $39.6^{\mathrm{b}}$ & 0.11 & $*$ & ns & $\mathrm{ns}$ \\
\hline 6 & $39.3^{\mathrm{a}}$ & $39.0^{\mathrm{b}}$ & $39.5^{\mathrm{a}}$ & $39.4^{\mathrm{a}}$ & 0.06 & $*$ & $\mathrm{~ns}$ & $\mathrm{~ns}$ \\
\hline Mean & $38.8^{\mathrm{a}}$ & $39.1^{\mathrm{a}}$ & $39.5^{\mathrm{b}}$ & $39.3^{\mathrm{ab}}$ & 0.07 & $*$ & ns & $\mathrm{ns}$ \\
\hline \multicolumn{9}{|l|}{$\mathrm{NH}_{3}-\mathrm{N}(\mathrm{mg} / \mathrm{dL})$} \\
\hline $0 \mathrm{~h}$-post feeding & 7.5 & 7.2 & 6.5 & 7.1 & 0.44 & ns & ns & $\mathrm{ns}$ \\
\hline 2 & $20.0^{\mathrm{ab}}$ & $17.8^{\mathrm{b}}$ & $24.1^{\mathrm{a}}$ & $22.8^{\mathrm{a}}$ & 0.61 & $* *$ & ns & $\mathrm{ns}$ \\
\hline 4 & 18.7 & 21.4 & 18.5 & 18.4 & 0.69 & ns & $\mathrm{ns}$ & $\mathrm{ns}$ \\
\hline 6 & 11.6 & 14.2 & 9.9 & 11.7 & 0.78 & ns & $\mathrm{ns}$ & $\mathrm{ns}$ \\
\hline Mean & 14.4 & 15.2 & 14.8 & 15.0 & 0.35 & ns & ns & $\mathrm{ns}$ \\
\hline
\end{tabular}

${ }^{1} \mathrm{R}: \mathrm{C}$ ratio $=$ Roughage to concentrate ratio. ${ }^{2} \mathrm{Nrpm}=$ Non supplement rain tree pod meal. $\mathrm{RPM}=$ Supplement rain tree pod meal.

${ }^{3} \mathrm{~A}=$ Roughage to concentrate ratio. $\mathrm{B}=$ Non or supplement rain tree pod meal. $\mathrm{A} \times \mathrm{B}=\mathrm{R}: \mathrm{C}$ ratio and non or supplement $\mathrm{RPM}$ interaction.

$\mathrm{SEM}=$ Standard error of the mean, $* \mathrm{p}<0.05, * * \mathrm{p}<0.01, \mathrm{~ns}=$ No significance.

Condensed tannins in the diet have beneficial effects in mediating protein-tannin complexation, decreasing availability of feed protein for ruminal degradation and $\mathrm{NH}_{3}-\mathrm{N}$ release as found by Makkar (2003). However, in contrast to the present study, the ruminal concentration of $\mathrm{NH}_{3}-\mathrm{N}$ was not affected by RPM supplemented treatments.

\section{Effect on rumen microorganism population}

The numbers of total bacteria, R. albus (Table 4) and bacteria and fungi count, viable proteolytic bacteria (Table 3 ) were not affected by RPM supplementation. Pilajun and Wanapat (2012) also reported that supplementation with tannins and saponins rich-plants did not change the microbial population in swamp buffalo. However, other studies have demonstrated that plants containing tannins and saponins have antimicrobial properties (Patra and Saxena, 2009; Manasri et al., 2012). The inhibitory activity of tannins against bacteria has been linked to the ability of tannins to form complexes with the cell wall and membrane of bacteria causing morphological changes of the cell wall and the extracellular enzymes secreted (Jones et al., 1994). Different results obtained by these authors could be due to the different sources of diets, dose of tannins, animal type, feeding program and environmental conditions between the previous studies and the present work. In contrast, the number of fungal zoospores were decreased $(\mathrm{p}<0.05)$ with increasing concentrate ratio feeding (R:C 60:40). The results obtained could be due to less fiber and a lower $\mathrm{pH}$ which would decrease fiber digestibility (Cherdthong et al., 2010).

Furthermore, the use of real-time PCR technique found that the population of $F$. succinogenes and R. flavefaciens (Table 4) and viable cellulolytic and amylolytic bacteria (Table 3) were significantly different, responding to the level of roughage. As the results showed, the population of cellulolytic bacteria, $F$. succinogenes and $R$. flavefaciens in $\mathrm{R}: \mathrm{C}$ at 60:40 were higher, while amylolytic bacterial was lower than R:C at 40:60. Similarly to Anantasook and Wanapat (2012) who reported that the numbers of the three cellulolytic bacteria decreased with increased concentrate ratio in the diet. Moreover, Cherdthong et al. (2010) reported that R:C ratio of 75:25 could increase the cellulolytic bacteria while the amylolytic bacteria population was decreased. It is possible that dietary conditions might have influenced the reduced numbers of cellulolytic bacteria (Wanapat and Cherdthong, 2009). Moreover, rumen $\mathrm{pH}$ has been suggested as a factor governing bacterial attachment (Miron et al., 2001). Animals feeding on a high concentrate diet were affected with a decline of ruminal $\mathrm{pH}$, which was attributed to the inhibition of cellulolytic bacteria, since most ruminal cellulolytic bacteria are pH-sensitive (Russell and Wilson, 1996). The $\mathrm{pH}$ sensitivity can be explained by the intracellular $\mathrm{pH}$ regulation of cellulolytic bacteria. When 
Table 3. Effect of roughage to concentrate ratio and rain tree pod meal supplementation on microbial population in the rumen

\begin{tabular}{|c|c|c|c|c|c|c|c|c|}
\hline \multirow{3}{*}{ Item } & \multicolumn{4}{|c|}{$\mathrm{R}: \mathrm{C}$ ratio $^{1}$} & \multirow{3}{*}{ SEM } & \multirow{2}{*}{\multicolumn{3}{|c|}{ Significance $^{3}$}} \\
\hline & \multicolumn{2}{|c|}{$60: 40$} & \multicolumn{2}{|c|}{$40: 60$} & & & & \\
\hline & nRPM & $\mathrm{RPM}^{2}$ & nRPM & RPM & & $\mathrm{A}$ & $\mathrm{B}$ & $\mathrm{A} \times \mathrm{B}$ \\
\hline \multicolumn{9}{|c|}{ Direct count, (cells/mL) } \\
\hline \multicolumn{9}{|l|}{ Bacteria, $\times 10^{9}$} \\
\hline 0 h-post feeding & 3.4 & 2.7 & 3.1 & 3.1 & 0.19 & ns & ns & ns \\
\hline 4 & 3.4 & 3.4 & 3.3 & 3.0 & 0.12 & $\mathrm{~ns}$ & ns & ns \\
\hline Mean & 3.4 & 3.0 & 3.2 & 3.0 & 0.14 & $\mathrm{~ns}$ & ns & ns \\
\hline \multicolumn{9}{|l|}{ Fungi, $\times 10^{4}$} \\
\hline 0 h-post feeding & 1.2 & 1.2 & 1.0 & 1.0 & 0.08 & ns & ns & ns \\
\hline 4 & $1.3^{\mathrm{a}}$ & $1.2^{\mathrm{ab}}$ & $0.9^{\mathrm{ab}}$ & $0.8^{\mathrm{b}}$ & 0.06 & $*$ & ns & ns \\
\hline Mean & $1.3^{\mathrm{a}}$ & $1.2^{\mathrm{a}}$ & $1.0^{\mathrm{b}}$ & $0.9^{\mathrm{b}}$ & 0.06 & $*$ & ns & ns \\
\hline \multicolumn{9}{|l|}{ Protozoa, $\times 10^{6}$} \\
\hline 0 h-post feeding & 2.9 & 1.9 & 2.4 & 2.0 & 0.22 & ns & ns & ns \\
\hline 4 & $3.2^{\mathrm{a}}$ & $2.4^{\mathrm{b}}$ & $1.9^{\mathrm{c}}$ & $1.7^{\mathrm{c}}$ & 0.06 & $* *$ & $*$ & ns \\
\hline Mean & $3.1^{\mathrm{a}}$ & $2.2^{\mathrm{b}}$ & $2.2^{\mathrm{b}}$ & $1.9^{\mathrm{b}}$ & 0.12 & $*$ & $*$ & ns \\
\hline \multicolumn{9}{|c|}{ Total viable bacteria, $\times 10^{9} \mathrm{CFU} / \mathrm{mL}$} \\
\hline 0 h-post feeding & 0.6 & 0.4 & 0.8 & 0.8 & 0.87 & $\mathrm{~ns}$ & ns & ns \\
\hline 4 & 1.5 & 2.1 & 2.1 & 1.7 & 1.02 & ns & ns & ns \\
\hline Mean & 0.9 & 1.3 & 1.4 & 1.3 & 0.27 & $\mathrm{~ns}$ & ns & ns \\
\hline \multicolumn{9}{|c|}{ Cellulolytic bacteria, $\times 10^{8} \mathrm{CFU} / \mathrm{mL}$} \\
\hline $0 \mathrm{~h}$-post feeding & 7.1 & 7.1 & 5.8 & 5.5 & 0.98 & $\mathrm{~ns}$ & ns & ns \\
\hline 4 & $4.3^{\mathrm{ab}}$ & $6.8^{\mathrm{a}}$ & $1.2^{\mathrm{b}}$ & $2.1^{\mathrm{ab}}$ & 0.69 & $*$ & ns & ns \\
\hline Mean & 5.7 & 7.0 & 5.8 & 3.8 & 0.56 & $\mathrm{~ns}$ & ns & ns \\
\hline \multicolumn{9}{|c|}{ Proteolytic bacteria, $\times 10^{7} \mathrm{CFU} / \mathrm{mL}$} \\
\hline 0 h-post feeding & 1.3 & 1.4 & 1.4 & 1.5 & 0.41 & $\mathrm{~ns}$ & ns & ns \\
\hline 4 & 1.3 & 1.4 & 1.4 & 1.5 & 0.18 & ns & ns & ns \\
\hline Mean & 1.3 & 1.4 & 1.5 & 1.5 & 0.27 & ns & ns & ns \\
\hline \multicolumn{9}{|c|}{ Amylolytic bacterial, $\times 10^{7} \mathrm{CFU} / \mathrm{mL}$} \\
\hline $0 \mathrm{~h}$-post feeding & 3.3 & 2.7 & 3.6 & 3.8 & 2.68 & $\mathrm{~ns}$ & ns & ns \\
\hline 4 & $1.3^{\mathrm{a}}$ & $2.2^{\mathrm{ab}}$ & $2.4^{\mathrm{ab}}$ & $3.2^{\mathrm{b}}$ & 0.63 & $*$ & ns & $\mathrm{ns}$ \\
\hline Mean & $2.3^{\mathrm{a}}$ & $2.5^{\mathrm{a}}$ & $3.0^{\mathrm{ab}}$ & $3.5^{\mathrm{b}}$ & 0.31 & $*$ & $\mathrm{~ns}$ & $\mathrm{~ns}$ \\
\hline
\end{tabular}

${ }^{1} \mathrm{R}: \mathrm{C}$ ratio $=$ Roughage to concentrate ratio. ${ }^{2} \mathrm{Nrpm}=$ Non supplement rain tree pod meal, $\mathrm{RPM}=$ supplement rain tree pod meal.

${ }^{3} \mathrm{~A}=$ Roughage to concentrate ratio, $\mathrm{B}=$ Non or supplement rain tree pod meal, $\mathrm{A} \times \mathrm{B}=\mathrm{R}: \mathrm{C}$ ratio and non or supplement RPM interaction.

SEM $=$ Standard error of the mean, $* \mathrm{p}<0.05, * * \mathrm{p}<0.01, \mathrm{~ns}=$ No significance.

the extracellular $\mathrm{pH}$ of acid-sensitive bacteria declines, the hence leads to anion toxicity and product inhibition (Russell intracellular $\mathrm{pH}$ is relatively stable. While the increase in and Wilson, 1996). Furthermore, the population of $F$. the transmembrane $\mathrm{pH}$ gradient causes a logarithmic succinogenes, was found to be higher with supplementation accumulation of intracellular fermentation acid anions and by RPM, presumably as a consequence of the suppression

Table 4. Effect of roughage to concentrate ratio and rain tree pod meal supplementation on microbial population using real-time PCR techniques (copies/mL of rumen content)

\begin{tabular}{|c|c|c|c|c|c|c|c|c|}
\hline & \multicolumn{4}{|c|}{$\mathrm{R}: \mathrm{C}$ ratio $^{1}$} & \multirow{3}{*}{ SEM } & \multirow{2}{*}{\multicolumn{3}{|c|}{ Significance $^{3}$}} \\
\hline & \multicolumn{2}{|c|}{$60: 40$} & \multicolumn{2}{|c|}{$40: 60$} & & & & \\
\hline & nRPM & $\mathrm{RPM}^{2}$ & nRPM & RPM & & $\mathrm{A}$ & $\mathrm{B}$ & $\mathrm{A} \times \mathrm{B}$ \\
\hline Total bacteria $\left(10^{10}\right)$ & 4.5 & 4.7 & 5.6 & 5.5 & 0.43 & ns & ns & ns \\
\hline F. Succinogenes $\left(10^{8}\right)$ & $8.3^{\mathrm{a}}$ & $8.5^{\mathrm{a}}$ & $5.7^{\mathrm{c}}$ & $6.2^{\mathrm{b}}$ & 0.15 & $*$ & $*$ & $\mathrm{~ns}$ \\
\hline R. Flavefaciens $\left(10^{7}\right)$ & $6.6^{\mathrm{a}}$ & $6.9^{\mathrm{a}}$ & $4.9^{\mathrm{b}}$ & $5.2^{\mathrm{b}}$ & 0.17 & $*$ & ns & $\mathrm{ns}$ \\
\hline R. albus $\left(10^{6}\right)$ & 7.1 & 6.6 & 6.0 & 6.3 & 0.23 & ns & ns & ns \\
\hline Methanogens $\left(10^{6}\right)$ & $4.3^{\mathrm{a}}$ & $2.4^{\mathrm{b}}$ & $2.3^{\mathrm{b}}$ & $1.4^{\mathrm{c}}$ & 0.21 & $*$ & $*$ & $\mathrm{~ns}$ \\
\hline Protozoa $\left(10^{5}\right)$ & $5.2^{\mathrm{a}}$ & $3.4^{\mathrm{b}}$ & $2.9^{\mathrm{b}}$ & $1.1^{\mathrm{c}}$ & 0.19 & $*$ & $*$ & $\mathrm{~ns}$ \\
\hline
\end{tabular}

${ }^{1} \mathrm{R}: \mathrm{C}$ ratio $=$ Roughage to concentrate ratio. ${ }^{2} \mathrm{Nrpm}=$ Non supplement rain tree pod meal, $\mathrm{RPM}=$ Supplement rain tree pod meal.

${ }^{3} \mathrm{~A}=$ Roughage to concentrate ratio, $\mathrm{B}=$ Non or supplement rain tree pod meal, $\mathrm{A} \times \mathrm{B}=\mathrm{R}: \mathrm{C}$ ratio and non or supplement RPM interaction.

SEM $=$ Standard error of the mean, ${ }^{*} \mathrm{p}<0.05, * * \mathrm{p}<0.01, \mathrm{~ns}=$ No significance. 
of protozoal and methanogens numbers. Kurihara et al. (1968) reported that a decrease in bacterial numbers may be caused by the above mentioned predation of protozoa on the bacteria. Therefore, rumen bacterial population could be maintained due to a decreased protozoal population.

Feeding a high concentrate and supplementing with RPM decreased the protozoal (Tables 3 and 4) and methanogens population (Table 4). Van Soest (1982) found that feeding high concentrate diet could reduce the protozoal population. Similarly to Mackie et al. (1978) who reported that protozoal concentrations usually begin to decrease when the level of concentrate exceeds $60 \%$. In contrast with Cherdthong et al. (2010) who found that protozoal populations were linearly increased with an increasing level of concentrate. While, Anantasook and Wanapat (2012) reported that the population of methanogens in the total bacterial population decreased with an increasing level of concentrate and RPM supplementation. Poungchompu et al. (2009) also found that the percentage of methanogens in ruminal decreased with feeding high concentrate. Moreover, protozoal numbers were decreased with the addition of tea saponin at $0.4 \mathrm{mg} / \mathrm{mL}$ (Goel et al., 2008), and supplementation with RPM (Anantasook and Wanapat, 2012). Furthermore, plants containing tannins and saponins could reduce methanogens as reported by Bhatta et al. (2009) and Animut et al. (2008). The action of condensed tannins are thought to directly inhibit methanogens (Tavendale et al., 2005), while saponins have been shown in vitro to inhibit protozoa as well as limit hydrogen availability for methanogensis (Guo et al., 2008). Wallace et al. (2002) indicated that saponins might kill or damage protozoa by forming complexes with sterols in the protozoal membrane surface. The membrane may become impaired and eventually disintegrate. Nevertheless, several reports showed no effect of plant containing tannins and saponins on protozoa and methanogen numbers (Wina et al., 2005; Norrapoke et al., 2010; Pilajun and Wanapat, 2012).

\section{CONCLUSIONS AND RECOMMENDATIONS}

Supplementation of RPM at $60 \mathrm{~g} / \mathrm{kg}$ of total DM intake and feeding different concentrate ratios resulted in changing the rumen microorganisms, especially, when animals were supplemented with RPM, which significantly reduced protozoa and methanogens population. Results obtained herein could be used in manipulating the rumen fermentation in ruminants.

\section{ACKNOWLEDGEMENTS}

The authors express sincere thanks to the Tropical Feed Resources Research and Development Center (TROFREC),
Department of Animal Science, Faculty of Agriculture, Khon Kaen University, The Office of the Higher Education Commission and Thailand Research Fund (TRF) through the Royal Golden Jubilee $\mathrm{PhD}$ Program for providing financial support for the research and use of research facilities. In addition, thanks are extended to the Agricultural Biotechnology Research Center, Khon Kaen University for the permission to perform real-time PCR analysis and for technical support.

\section{REFERENCES}

Anantasook, N. and M. Wanapat. 2012. Influence of rain tree pod meal supplementation on rice straw based diets using in vitro gas fermentation technique. Asian-Aust. J. Anim. Sci. 25:325334.

Anantasook, N., M. Wanapat, A. Cherdthong, and P. Gunun. 2013. Effect of plants containing secondary compounds with palm oil on feed intake, digestibility, microbial protein synthesis and microbial population in dairy cows. Asian Australas. J. Anim. Sci. 26:820-826.

Animut, G., A. L. Goetsch, R. Puchala, A. K. Patra, T. Sahlu, V. H. Varel, and J. Wells. 2008. Methane emission by goats consuming diets with different levels of condensed tannins from lespedeza. Anim. Feed Sci. Technol. 144:212-227.

Bhatta, R., Y. Uyeno, K. Tajima, A. Takenaka, Y. Yabumoto, I. Nonaka, O. Enishi, and M. Kurihara. 2009. Difference in the nature of tannins on in vitro ruminal methane and volatile fatty acid production and on methanogenic archaea and protozoal populations. J. Dairy Sci. 92:5512-5522.

Burns, R. E. 1971. Method for estimation of tannin in the grain sorghum. Agron. J. 163:511-512.

Chanthakhoun, V., M. Wanapat, C. Wachirapakorn, and S. Wanapat. 2011. Effect of legume (Phaseolus calcaratus) hay supplementation on rumen microorganisms, fermentation and nutrient digestibility in swamp buffalo. Livest. Sci. 140:17-23.

Chareprasert, S., J. Piapukiew, S. Thienhirun, and J. S. Anthony Whalley. 2006. Endophytic fungi of teak leaves Tectona grandis L. and rain tree leaves Samanea saman Merr. World J. Microbiol. Biotechnol. 22:481-486.

Cherdthong, A., M. Wanapat, P. Kongmun, R. Pilajan, and P. Khejornsart. 2010. Rumen fermentation, Microbial protein synthesis and cellulolytic bacterial population of swamp buffaloes as affected by roughage to concentrate ratio. J. Anim. Vet. Adv. 9:1667-1675.

Decandia, M., M. Sitzia, A. Cabiddu, D. Kababya, and G. Molle. 2000. The use of polyethylene glicol to reduce the antinutritional effects of tannins in goats fed woody species. Small Rum. Res. 38:157-164.

Denman, S. E., N. Tomkins, and C. S. McSweeney. 2005. Monitoring the effect of bromochloromethane on methanogen populations within the rumen using qPCR. In: 2nd International Symposium on Greenhouse Gases and Animal Agriculture (Ed. C. R. Soliva, J. Takahashi, and M. Kreuzer). P. 112 ETH Zurich, Switzerland.

Flachowsky, G., K. Erdmann, P. Lebzien, and L. Hüther. 2006. Investigations on the influence of roughage/concentrate ratio and linseed oil supplementation on rumen fermentation and 
microbial protein yield in dairy cows. Slovak J. Anim. Sci. 39: 3-9.

Gaafar, H. M. A., A. M. A. Mohi El-Din, M. I. Basiuoni, and K. F. A. El-Riedy. 2009. Effect of concentrate to roughage ratio and baker's yeast supplementation during hot season on performance of lactating buffaloes. Slovak. J. Anim. Sci. 42: 188-195.

Goel, G., H. P. S. Makkar, and K. Becker. 2008. Changes in microbial community structure, methanogenesis and rumen fermentation in response to saponin-rich fractions from different plant materials. J. Appl. Microbiol. 105:770-777.

Guo, Y. Q., J. X. Liu, Y. Lu, W. Y. Zhu, S. E. Denman, and C. S. McSweeney. 2008. Effect of tea saponin on methanogenesis, microbial community structure and expression of mcrA gene, in cultures of rumen microorganisms. Lett. Appl. Microbiol. 47:421-426

Hungate, R. E. 1969. The Rumen and Its Microbes. Academic Press. New York.

Jetana, T., S. Usawang, S. Thongruay, C. Vongpipatana, and S. Sophon. 2008. Effects of replacement of leucaena (Leucaena leucocephala) with rain tree pod (Samanea saman) as a protein-rich supplement for cattle production. In: Proceedings of the 46th Kasetsart University Annual Conference, Kasetsart, 29 January - 1 February, 2008. Subject: Animals and veterinary medicine, 2008 , pp. 39-45.

Jetana, T., C. Vongpipatana, S. Thongruay, S. Usawang, and S. Sophon. 2010. Apparent digestibility, nitrogen balance, ruminal microbial nitrogen production and blood metabolites in Thai brahman cattle fed a basal diet of rice straw and supplemented with some tropical protein-rich trees. AsianAust. J. Anim. Sci. 23:465-474.

Jones, G. A., T. A. McAllister, K. J. Cheng, and A. D. Muir. 1994. Effect of sainfoin (Onobrychis viciifolia Scop) on growth and proteolysis by 4 strains of rumen bacteria: resistance of Prevotella (Bacteroides) ruminicola B14. Appl. Environ. Microbiol. 60:1374-1378.

Kamra, D. N., A. K. Patra, P. N. Chatterjee, K. Ravindra, A. Neeta, and L. C. Chaudhary. 2008. Effect of plant extract on methanogenesis and microbial profile of the rumen of buffalo. A brief overview. Aust. J. Exp. Agric. 48:175-178.

Koike, S. and Y. Kobayashi. 2001. Develop and use of competitive PCR assays for the rumen cellulolytic bacteria: Fibrobactor succinogenes, Ruminococcus albus and Ruminococcus flavefaciens. FEMS Microbiol. Lett. 204:361-366.

Kurihara, Y., J. Margaret Eadie, P. N. Hobson, and S. O. Mann. 1968. Relationship between bacteria and ciliate protozoa in the sheep rumen. J. Gen. Microbiol. 51:267-288.

Kwon, J. H., J. Belanger, M. R. Pare, and V. A. Yaylayan. 2003. Application of the microwave-assisted process (MAPTM) to the fast excretion of ginseng saponins. Food Res. Int. 36:491498.

Kongmun, P., M. Wanapat, P. Pakdee, and C. Navanukraw. 2010. Effect of coconut oil and garlic powder on in vitro fermentation using gas production technique. Livest. Sci. 127: 38-44.

Kreuzer, M., D. N. Kamra, and C. R. Soliva. 2009. Utilizing the natural resources of the tropics: plants and plant extracts mitigating methane in ruminants. Proceedings of Animal Nutrition Association World Conference, I. 96-98.
Mackie, R. I., F. M. C. Gilchrist, A. M. Robberts, P. E. Hannah, and H. M. Schwartz. 1978. Microbiological and chemical changes in the rumen during the stepwise adaptation of sheep to high concentrate diets. J. Agric. Sci. 90:241-254.

Makkar, H. P. S. 2003. Effects and fate of tannins in ruminant animals, adaptation to tannins, and strategies to overcome detrimental effects of feeding tannin-rich feeds. Small Rum. Res. 49:241-256.

Manasri, N., M. Wanapat, and C. Navanukraw. 2012. Improving rumen fermentation and feed digestibility in cattle by mangosteen peel and garlic pellet supplementation. Livest. Sci. 148:291-295.

Mao, H. L., J. K. Wang, Y. Y. Zhou, and J. X. Liu. 2010. Effects of addition of tea saponins and soybean oil on methane production, fermentation and microbial population in the rumen of Growing lambs. Livst. Sci. 129:56-62.

Norrapoke, T., M. Wanapat, and S. Wanapat. 2012. Effects of protein level and mangosteen peel pellets (Mago-pel) in concentrate diets on rumen fermentation and milk production in lactating dairy crossbreds. Asian-Aust. J. Anim. Sci. 25:971979.

Patra, A. K. 2007. Nutritional management in organic livestock farming for improved ruminant health and production-An overview. Livest. Res. Rural. Dev. 19(3).

Patra, A. K., D. N. Kamra, and N. Agarwal. 2006. Effect of plant extracts on in vitro methanogenesis, enzyme activities and fermentation of feed in rumen liquor of buffalo. Anim. Feed Sci. Technol. 128:276-291.

Patra, A. K. and J. Saxena. 2009. A review of the effect and mode of action of saponins on microbial population and fermentation in the rumen and ruminant production. Nutr. Res. Rev. 22: 204-219.

Pilajun, R. and M. Wanapat. 2012. Microbial population in the rumen of swamp buffalo (Bubalus bubalis) as influenced by coconut oil and mangosteen peel supplementation. J. Anim. Physiol. Anim. Nutr. 97:439-445. DOI: 10.1111/j.14390396.2012.01279.

Poungchompu, O., M. Wanapat, C. Wachirapakorn, S. Wanapat, and A. Cherdthong. 2009. Manipulation of ruminal fermentation and methane production by dietary saponins and tannins from mangosteen peel and soapberry fruit. Arch. Anim. Nutr. 63:389-400.

Ramirez-Restrepo, C. A., T. N. Barry, N. Lopez-Villalobos, N. Kemp, and T. G. Harvey. 2005. Use of Lotus corniculatus containing condensed tannins to increase reproductive efficiency in ewes under commercial dry land farming conditions. Anim. Feed Sci. Technol. 121:23-43.

Russell, J. B. and D. B. Wilson. 1996. Why are ruminal cellulolytic bacteria unable to digest at low pH. J. Dairy Sci. 79:1503-1509.

SAS. 1996. User's guide: Statistic, Version 5. Edition. SAS. Inst, Cary, NC, USA.

Steel, R. G. D. and J. H. Torrie. 1980. Principles and procedures of statistics. McGraw Hill Book Co., New York, NY, USA.

Tavendale, M. H. L., P. Meagher, D. Pacheco, N. Walker, G. T. Attwood, and S. Sivakumaran. 2005. Methane production from in vitro rumen incubations with Lotus pedunculatus and Medicago sativa, and effects of extractable condensed tannin fractions on methanogenesis. Anim. Feed Sci. Technol. 123: 403-419. 
Van Soest, P. J. 1982. Nutritional ecology of the ruminant. O\&B Books Inc, Corvallis.

Van soest, P. J. 1994. Nutritional ecology of the ruminant, (Cornell University Press: London).

Wallace, R. J., N. R. McEwan, F. M. McInotoch, B. Teferedegne, and C. J. Newbold. 2002. Natural products as manipulators of rumen fermentation. Asian-Aust. J. Anim. Sci. 15:1458-1468.

Wanapat, M. and A. Cherdthong. 2009. Use of real-time PCR technique in studying rumen cellulolytic bacteria population as affected by level of roughage in swamp buffaloes. Curr. Microbiol. 58:294-299.

Wang, C. J., S. P. Wang, and H. Zhou. 2009. Influences of flavomycin, ropadiar, and saponin on nutrient digestibility, rumen fermentation, and methane emission from sheep. Anim. Feed Sci. Technol. 148:157-166.
Wina, E., S. Muetzel, E. Hoffmann, H. P. S. Makkar, and K. Becker. 2005. Saponins containing methanol extract of Sapindus rarak affect microbial fermentation, microbial activity and microbial community structure in vitro. Anim. Feed Sci. Technol. 121:159-174.

Woese, C. R., O. Kandler, and J. L. Wheelis. 1990. Towards a natural system of organisms: proposal for the domains Archaea, Bacteria \& Eucarya. Proc. Nat. Acad. Sci. 87:4576-4579.

Wright, A. G., A. J. Williams, B. Winder, C. T. Christophersen, S. L. Rodgers, and K. D. Smith. 2004. Molecular diversity of rumen methanogens from sheep in western Australia. Appl. Environ. Microbiol. 70:1263-1270.

$\mathrm{Yu}, \mathrm{Z}$. and M. Morrison. 2004. Improved extraction of PCRquality community DNA from digesta and fecal samples. BioTechniques 36:808-812. 